\title{
INCIDENCE OF GASTRIC AND DUODENAL ULCER IN THE BRITISH ARMY IN 1955
}

\author{
BY \\ J. H. BARON* AND R. VAUGHAN JONES† \\ Lately Royal Herbert Military Hospital, Woolwich
}

No estimate of the prevalence of gastric and duodenal ulcer is entirely satisfactory. It has been generally felt however that there has been a great increase in the incidence of duodenal ulcer in the last three decades. In the first world war up to the end of 1915 (i.e. in 16 months), there were 109 medical discharges from the Army for "inflammation and ulceration of the stomach". In World War II up to the end of 1941 (i.e. in 28 months), there were 23,574 (Tidy, 1943).

Doll (1952) has reviewed the methods available for determining the true incidence of peptic ulceration in the community at large. National mortality statistics are unsatisfactory because the disease has a low fatality rate. Selection factors vary enormously in various hospital services. He concluded that a population survey is the method of choice if the group chosen is typical of the population, and Doll, Jones, and Buckatzsch (1951) made such a survey, mainly in London.

Individual medical documents are available for the whole British Army, which emphasises a suitably large population, and we have analysed the morbidity from peptic ulcer diagnosed for the first time in 1955 in male personnel.

\section{METHOD}

Copies of summaries of the medical histories of hospital in-patients for the entire British Army are available centrally, and particulars of all admissions to hospital are coded on punch cards under a number of headings.

In 1955 diagnoses of gastric, duodenal, or peptic ulceration were made in 1,203 Army personnel.

The medical documents could not be traced in fourteen cases, but each of the remaining 1,189 (98.8 per cent.) was examined. 197 were excluded because: the diagnosis had first been made before 1955 (185 patients); the patient was a female (9); there had been errors of coding (3).

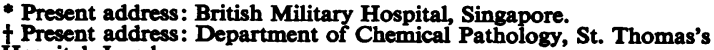
Hospital, London.
}

The remaining 992 male servicemen were admitted to hospital in 1955 for the first time with a diagnosis of peptic ulcer. In 138 patients the diagnosis was presumptive, either because they had not had a barium meal (40) or because the results were negative (98). For the purpose of the survey the remaining 854 patients were considered to have had ulcers proven.

The criteria of proven diagnosis adopted were as follows:

(1) 664 duodenal and eighty gastric ulcers were demonstrated by barium meal to the satisfaction of the radiologist concerned, as were three ulcers of which the site was not stated. Eight patients had both gastric and duodenal ulcers. Clearly the diagnostic criteria vary between different radiologists. Doll and others (1951) wrote concerning a similar situation in their survey:

"The larger number of radiologists concerned introduces a random element which, in the absence of a single uniform opinion, is the best safeguard against bias in favour of any one group".

(2) 85 duodenal, fourteen gastric, and two ulcers with site not specified were found at laparotomy to have perforated.

(3) Two duodenal ulcers were found at laparotomy for haematemesis.

(4) Eight duodenal and six gastric ulcers were found at elective gastric surgery.

(5) Neither gastroscopy nor autopsy contributed cases to this series.

In some cases the diagnosis was established by more than one method in the course of the year, and therefore the totals of the above groups add up to more than the total 854 patients.

All ulcers were classified by us as either duodenal or gastric. Ten patients had ulcers of both stomach and duodenum, and five had ulcers the site of which was not stated. These fifteen patients are omitted from subsequent detailed consideration. 
The results of analysis of the remaining 839 patients are presented below. Attack rates have been calculated from figures supplied by the Adjutant General's branch for the strength of the Army in 1955 and are average figures for the year for male personnel. These figures cannot be published and only approximate figures may be given in the text. The ages given are ages at the time of diagnosis, not at onset of symptoms.

\section{RESULTS}

There were 864 ulcers in 854 men, and the patients may be classified as follows:

$\begin{array}{lr}\text { Duodenal ulcers } & 742 \\ \text { Gastric ulcers } & 97 \\ \text { Peptic ulcers-site not specified } & 5 \\ \text { Ulcers at both sites } & 10\end{array}$

The incidence of duodenal ulcer was 1.8 per thousand men, and that of gastric ulcer 0.2 per thousand. The ratio of duodenal to gastric ulcers, excluding ulcers at both sites, is $7 \cdot 65: 1$. The figures of the various age groups are given in Table $I$ and the attack rate per thousand men by ages in Table II.

TABLE I

AGE INCIDENCE AND RATIO OF DUODENAL : GASTRIC ULCERS

\begin{tabular}{c|c|c|c|c|c}
\hline \multirow{2}{*}{$\begin{array}{c}\text { Age } \\
\text { Group }\end{array}$} & \multicolumn{2}{|c|}{ Duodenal Ulcer } & \multicolumn{2}{|c|}{ Gastric Ulcer } & \multicolumn{1}{c}{$\begin{array}{c}\text { Ratio } \\
\text { (yrs) }\end{array}$} \\
\cline { 2 - 3 } & $\begin{array}{c}\text { Number } \\
\text { of Cases }\end{array}$ & $\begin{array}{c}\text { Per- } \\
\text { centage } \\
\text { Distri- } \\
\text { bution }\end{array}$ & $\begin{array}{c}\text { Number } \\
\text { of Cases }\end{array}$ & $\begin{array}{c}\text { Per- } \\
\text { centage } \\
\text { Distri- } \\
\text { bution }\end{array}$ & $\begin{array}{c}\text { Duodenal:Gastric } \\
\text { Ulcer }\end{array}$ \\
\hline $17-19$ & 160 & $21 \cdot 6$ & 21 & $21 \cdot 6$ & $7 \cdot 6: 1$ \\
$20-24$ & 247 & $33 \cdot 3$ & $29 \cdot$ & $29 \cdot 9$ & $8 \cdot 5: 1$ \\
$25-29$ & 104 & $14 \cdot 0$ & 13 & $13 \cdot 4$ & $8 \cdot 0: 1$ \\
$30-34$ & 67 & $9 \cdot 0$ & 8 & $8 \cdot 2$ & $8 \cdot 4: 1$ \\
$35-39$ & 71 & $9 \cdot 6$ & 11 & $11 \cdot 3$ & $6 \cdot 5: 1$ \\
$40-44$ & 62 & $8 \cdot 4$ & 5 & $5 \cdot 2$ & $12 \cdot 4: 1$ \\
$45+$ & 31 & $4 \cdot 2$ & 10 & $10 \cdot 3$ & $3 \cdot 1: 1$ \\
\hline Total & 742 & 100 & 97 & 100 & $7 \cdot 65: 1$ \\
\hline
\end{tabular}

TABLE II

ATTACK RATE FOR DUODENAL ULCER AND GASTRIC ULCER PER THOUSAND MALE ARMY PERSONNEL, BY AGE GROUP

\begin{tabular}{|c|c|c|c|c|c|}
\hline \multirow{2}{*}{$\begin{array}{l}\text { Age } \\
\text { Group } \\
\text { (yrs) }\end{array}$} & \multicolumn{2}{|c|}{ Duodenal Ulcer } & \multicolumn{2}{|c|}{ Gastric Ulcer } & \multirow{2}{*}{$\begin{array}{l}\text { Incidence of All } \\
\text { Types of Ulcer } \\
\text { (per } 1,000 \text { men) }\end{array}$} \\
\hline & $\begin{array}{c}\text { No. of } \\
\text { Cases }\end{array}$ & $\begin{array}{c}\text { Incidence } \\
\text { (per 1,000 } \\
\text { men) }\end{array}$ & $\begin{array}{c}\text { No. of } \\
\text { Cases }\end{array}$ & $\begin{array}{c}\text { Incidence } \\
\text { (per 1,000 } \\
\text { men) }\end{array}$ & \\
\hline $\begin{array}{l}17-19 \\
20-24 \\
25-29 \\
30-34 \\
35-39 \\
40-44 \\
45+\end{array}$ & $\begin{array}{r}160 \\
247 \\
104 \\
67 \\
71 \\
62 \\
31\end{array}$ & $\begin{array}{l}1 \cdot 0 \\
1 \cdot 5 \\
3 \cdot 7 \\
3 \cdot 8 \\
4 \cdot 1 \\
4 \cdot 5 \\
3 \cdot 7\end{array}$ & $\begin{array}{r}21 \\
29 \\
13 \\
8 \\
11 \\
5 \\
10\end{array}$ & $\begin{array}{l}0 \cdot 1 \\
0 \cdot 2 \\
0 \cdot 5 \\
0 \cdot 5 \\
0 \cdot 6 \\
0 \cdot 4 \\
1 \cdot 2\end{array}$ & $\begin{array}{l}1 \cdot 1 \\
1 \cdot 7 \\
4 \cdot 1 \\
4 \cdot 3 \\
4 \cdot 7 \\
4 \cdot 9 \\
4 \cdot 9\end{array}$ \\
\hline Total & 742 & $1 \cdot 8$ & 97 & 0.2 & $2 \cdot 1$ \\
\hline
\end{tabular}

Perforated ulcers are shown separately in Table III.

TABLE III

PERCENTAGE OF ULCERS WHICH PRESENTED WITH PERFORATION, BY AGE GROUP

\begin{tabular}{c|c|c|c|c}
\hline $\begin{array}{c}\text { Age } \\
\text { Group }\end{array}$ & \multicolumn{2}{|c|}{ Duodenal Ulcer } & \multicolumn{2}{c}{ Gastric } \\
\cline { 2 - 4 } & $\begin{array}{c}\text { Number } \\
\text { Perforated }\end{array}$ & $\begin{array}{c}\text { Percentage } \\
\text { Perforated }\end{array}$ & $\begin{array}{c}\text { Number } \\
\text { Perforated }\end{array}$ & $\begin{array}{c}\text { Percentage } \\
\text { Perforated }\end{array}$ \\
\hline $17-19$ & 27 & $16 \cdot 9$ & 4 & 19 \\
$20-24$ & 22 & $8 \cdot 9$ & 6 & 21 \\
$25-29$ & 14 & $13 \cdot 5$ & 2 & 15 \\
$30-34$ & 9 & $13 \cdot 4$ & 0 & -1 \\
$35-39$ & 5 & $7 \cdot 0$ & 0 & 20 \\
$40-44$ & 4 & $6 \cdot 5$ & 1 & 10 \\
$45+$ & 4 & $13 \cdot 0$ & 1 & 14.4 \\
\hline Total & 85 & $11 \cdot 5$ & 14 & \\
\hline
\end{tabular}

Nature of the Population Surveyed

In 1955 the British Armed Forces received by conscription for 2 years almost all young men not medically unfit. Most entered the Army at the age of 18 , but some were allowed deferment for a period of years. Thus National Servicemen form the vast majority of men aged 17-20 in the Army, many of those aged 20-24, and some of those aged 25-29. All others are on regular engagements.

Recruits are drawn from all parts of the United Kingdom, and include all social classes and most occupations, except that certain groups, notably coal miners, merchant seamen, and farm workers, are exempted from military service altogether. The National Servicemen are to that extent representative of the British population. There are, however, certain minimum medical standards for entry; and patients with known peptic ulcers are not accepted. Regular soldiers are not representative of the population of Britain, as they have volunteered for a particular type of life, have been especially selected for fitness, would have been rejected if they had had an ulcer, and might well have been discharged if they had developed one.

It is widely known in the Army that stomach trouble may lead to a period in hospital and even to invaliding out of the Army. These events probably tend to make long-service regulars delay reporting their dyspepsia and also to have the opposite effect on National Servicemen. Army routine with fairly long intervals between meals tends to exacerbate dyspeptic symptoms. Almost all patients with major dyspepsia are referred for barium meal examination at a hospital, and, unlike civilian life, there is no difficulty in admitting such patients to hospital for investigation and treatment.

We have studied other population surveys and their selectivity. Knutsen and Selvaag (1947) 
analysed the extra ration certificates for radiologically proven ulcers in 1942 in Drammen, a representative town of 25,000 inhabitants in occupied Norway. The incentive of extra rations guaranteed the inclusion of almost all dyspeptics. Their paper does not, however, mention the whereabouts at that time of males of military age. Doll and others (1951) do not consider the community they studied to be representative of the general population with reference to age, sex, geographical location, and occupation.

\section{INCIDENCE OF DUODENAL ULCER}

Table II shows the incidence of newly-diagnosed duodenal ulcers by age groups. It is considered that the 19 year-olds are the group in this series likely to correspond most closely to the same age group of the whole male population of the United Kingdom, as selective factors operate least strongly at this age In about 100,000 soldiers aged 19, there were 102 duodenal ulcers, that is, 1.0 per thousand. Figures for comparison in other series are scanty. Knutsen and Selvaag found three duodenal ulcers in 903 males aged 15-19, and Doll and others (1951) found one in 199 males aged 14-19 years.

The attack rate for duodenal ulcer rises to a maximum of $4 \cdot 5$ per thousand in the $40-44$ age group. This peak age group is the same as that found by Doll and others ( $4 \cdot 1$ per cent. at $40-44)$ and Knutsen and Selvaag ( $4 \cdot 0$ per cent at $40-49)$, but the overall incidence in these surveys is nine times that in the present series. The non-recruitment to the Army of known ulcer sufferers, the invaliding of many ulcer patients, and the restriction of this series to ulcers diagnosed for the first time in 1955 may account for these differences.

In 1942-5, 63,957 duodenal ulcers were diagnosed in the United States Army, giving an annual rate of 2.51 per thousand men on the strength. The figures were not analysed by ages and are based on a preliminary sample only, the bases for diagnosis not being stated. The 1937-41 figures, which are final, give a similar figure of 2.47 per thousand (Hamilton, Sullivan, and Palmer, 1952).

\section{INCIDENCE OF GASTRIC ULCER}

There were seventeen gastric ulcers in about 100,000 19-year-old soldiers, an attack rate of $0 \cdot 16$ per thousand. There were no patients with gastric ulcers at this age in the series of Knutsen and Selvaag or Doll and others. The attack rate for gastric ulcer in the present series appears to rise with age.

\section{DuOdenal/Gastric Ulcer Ratio}

Table I shows that the ratio of duodenal to gastric ulcer in all age groups was $7 \cdot 65: 1$. This may be compared with 10:1 in the United States Army in 1942-5, and 5:1 in 1937-41 (Hamilton and others, 1952); their figures are also based on in-patient hospital series. Tidy (1943) found a ratio of 4.6:1 in an analysis of 800 military patients discharged from hospital in 1942.

The ratio under 45 years of age in the present series is $8 \cdot 2: 1$. This may be compared with $2 \cdot 3: 1$ in the men under 45 years of age reported by Doll and others, and of $2 \cdot 3: 1$ of men under 50 years of age in the Drammen series. Two British civilian series of hospital in-patients and out-patients in London (Jones and Pollak, 1945) and Glasgow (Jamieson, Smith, and Scott, 1949) give ratios for men under 45 of $5 \cdot 5: 1$ and $13 \cdot 2: 1$ respectively. It is generally agreed that the ratio is higher in Scotland than in England, and the figure of $8 \cdot 2: 1$ in the Army, a mixed British population, is intermediate. The ratio varies slightly with age, but no conclusions have been drawn because of the small number of gastric ulcers.

\section{Perforated Ulcers}

Table III shows that 11.5 per cent. of duodenal ulcers and 14.4 per cent. of gastric ulcers presented with perforation. The comparable figures of Jones and Pollak (1943) are 11.7 per cent. of duodenal ulcers and 5.3 per cent. of gastric ulcers. These figures for duodenal ulcers are very similar to the 10.6 per cent. of Brooke (1950), who studied a one-fifth sample of all service cases admitted to E.M.S. hospitals 1940-7. She found in addition that 24.9 per cent. of 1,783 gastric ulcers presented with perforation, but the series here includes peptic ulcers (site not stated) and the validity of this large proportion may be questioned on that ground. It is also known that perforated ulcers thought at operation to be gastric may subsequently prove to be duodenal, a criticism that may also be applied to the present series.

\section{SUMMARY}

All in-patient case summaries of peptic, gastric, and duodenal ulcer patients in the British Army in 1955 were sought, and 99 per cent. were found, examined, and, assessed. In 1955, 742 duodenal and 97 gastric ulcers were diagnosed for the first time in approximately 400,000 male soldiers. The overall incidences of duodenal and gastric ulcers were 1.8 and 0.2 per thousand men respectively. The data 
were analysed by age, and attack rates were estimated in the various age groups for proven gastric and duodenal ulceration, together with the proportions presenting with perforation.

We are greatly indebted to Mr. D. T. Beeston of the Army Medical Statistics Branch, the War Office, for making available to us the medical records of patients with ulcers in the Army, and for his criticism and advice. We wish to thank the Director-General, Army Medical Services, for permission to publish.

\section{REFERENCES}

Brooke, E. M. (1950). Brit. med. J., 2, 560.

Doll, R. (1952). In "Modern Trends in Gastro-enterology", ed. F. Avery Jones, p. 361. Butterworth, London.

- Jones, F. Avery, and Buckatzsch, M. M. (1951). Med. res. Coun. spec. Rep. Ser., No. 276. H.M.S.O., London.

Hamilton, E. L., Sullivan, B. H., and Palmer, E. D., (1952). U.S. armed Forces med. J., 3, 831 .

Jamieson, R. A., Smith, W. E., and Scott., L. D. W. (1949). Brit. med. J., 1, 298.

Jones, F. Avery, and Pollak, H. (1945). Ibid., 1, 797.

Knutsen, B., and Selvaag, O. (1947). Acta. med. scand., Suppl. 196, p. 341 .

Tidy, H. (1943). Brit. med. J., 2, 473. 